\title{
A Panel Data Analysis of Electricity Demand in Pakistan
}

\section{Azam Amjad Chaudhry*}

\begin{abstract}
This paper looks at the economy-wide demand and the firm level demand for electricity in Pakistan. The economy wide estimation of electricity demand uses panel data from 63 countries from 1998-2008, and finds that the elasticity of demand for electricity with respect to per capita income is approximately 0.69, which implies that a 1\% increase in per capita income will lead to a $0.69 \%$ increase in the demand for electricity. The firm level analysis uses firm level data from the World Bank's Enterprise Survey for Pakistan and finds that the price elasticity of demand for electricity across all firms is approximately -0.57 , which implies that a $1 \%$ increase in electricity prices will lead to a $0.57 \%$ decrease in electricity demand across firms. Across sectors, the textile sector has the highest price elasticity of demand (-0.81) while the price elasticity of demand for firms in the electricity and electronics sector is the smallest (-0.31). Finally, firm level data is also used to estimate production functions in order to estimate the impact of electricity shortages on manufacturing output.
\end{abstract}

Keywords: Electricity, demand, industrial, price elasticity, Pakistan.

JEL Classification: Q41, E39, E01.

\section{Introduction}

In a period in Pakistan's economic history when the amount of electricity generated has fallen far short of the economy-wide demand, an analysis of electricity demand is critical both for understanding why the country has reached this point and for determining future policy measures to tackle this shortage. Although the topic of electricity demand in Pakistan is vast, this paper looks at the economy-wide demand for electricity and also focuses on industrial-level demand.

The questions that this paper attempts to answer are questions that the average Pakistani, the Pakistani business community, and Pakistani policymakers are attempting to answer: What will be the economy-wide

\footnotetext{
* Associate Professor and Dean, Department of Economics, Lahore School of Economics.
} 
demand for electricity in the coming years? What impact will higher electricity prices have on industrial demand for electricity? How does electricity affect industrial level output? Each question is a topic on which vast research is possible, but this paper looks at each using two unique datasets.

Most analyses that try to determine future electricity demand in Pakistan focus on time series data for Pakistan. This paper takes a different approach: Instead of just focusing on Pakistan, why not use historical data to see how electricity demand has grown over time in other countries? Using a unique panel dataset for 66 countries over 10 years taken from the International Energy Agency (IEA) and the Penn World Tables, the relationship between income per capita and electricity consumption per capita is estimated. This is then used to predict the growth in electricity demand in Pakistan over the next 5-10 years.

The second set of analyses using data taken from the World Bank Enterprise Surveys for Pakistan to construct a pane1 dataset for 402 firms over 4 years. This dataset is used to determine the elasticity of electricity demand with respect to the price of electricity across firms in Pakistan. This can be used to gauge the impact of industrial electricity price increases on the demand for electricity in the Pakistani industrial sector. This dataset is also used to estimate the production function for Pakistani firms; this estimation uses a production function that not only includes the usual factors of production, labor, and capital, but also includes electricity. With these results, one can estimate the impact of reductions in electricity supplies on industrial output.

The setup of the paper is as follows: Section II provides a brief background on electricity production and prices in Pakistan, and compares it with other countries. Section III uses the IEA dataset to estimate the elasticity of electricity consumption per capita with respect to real income per capita. Section IV uses the World Bank Enterprise Survey dataset to estimate the demand for electricity in the Pakistani manufacturing sector. Section V uses the World Bank Enterprise Survey dataset to estimate a firm level production function with electricity. Section VI contains conclusions.

\section{Background}

In 1947, Pakistan inherited $60 \mathrm{MW}$ of power generating capacity for a population of 31.5 million people and this was expanded to 119 MW by 1959 , just as the country was entering a phase of development that required reliable infrastructure. In the interim, the government acquired a majority shareholding of the Karachi Electric Supply Company (KESC) in 1952 and created the Water 
and Power Development Authority (WAPDA) in 1958, the purpose of which was to coordinate the development of schemes in water and power.

After its first 5 years of operation, WAPDA expanded the electricity generation capacity to $636 \mathrm{MW}$ and increased the number of electrified villages from 609 to 1,882 . This expansion picked up speed in the 1970s and 1980 s with the generating capacity rising to $1,331 \mathrm{MW}$ in 1970 , followed by further growth to 3,000 MW by 1980 and 7,000 MW in 1990/91.

However, rapid urbanization, industrialization, and rural electrification initiatives led to a significant growth in the demand for electricity (at a rate of $9-10 \%$ per annum) which meant that peak electricity demand fell short of supply by the early 1990s, requiring approximately 1,500-2,000 MW of load shedding. This shortfall was dealt with by the government with the 'Policy Framework of Package of Incentives for Private Sector Power Generation Projects' in 1994, leading to private sector initiatives in power development and an expansion of the supply to the point at which there was surplus power. But it should be noted that the policy led to the dramatic expansion of thermal projects and resulted in the reversal of the hyde1/thermal power generation mix. In 2000, the restructuring of WAPDA started, which eventually resulted in WAPDA being broken down into 14 separate units: Four thermal generating companies, nine distribution companies, and a transmission and distribution company. The main electric power producers in Pakistan are WAPDA, KESC, the Pakistan Atomic Energy Commission and a number of independent power producers (IPPs) established since 1994.

Table-1 shows the current situation in the electricity sector, with an estimated shortfall of 4,000 MW in 2008/09 and an estimated shortfall of 5,500 MW in 2009/10. Table-2 and Figure-1 show the breakdown of electricity supply in Pakistan and also illustrate the reversal of the hydel/ thermal power generation mix after the 1994 package. Figures 2 and 3 show the breakdown of electricity supplies in India and China in order to provide a comparison (the Appendix shows the breakdown of electricity supplies by region).

Table-1: Projection for Demand and Supply

\begin{tabular}{lcccc}
\hline No. & Year & Firm Supply (MW) & Peak Demand (MW) & Surplus/(Deficit) (MW) \\
\hline 1 & $2008 / 09$ & 15,055 & 19,080 & $(4,025)$ \\
2 & $2009 / 10$ & 15,055 & 20,584 & $(5,529$ \\
\hline
\end{tabular}


Table-2: Commercial Energy Supplies

\begin{tabular}{|c|c|c|c|c|c|c|c|}
\hline \multicolumn{8}{|c|}{ Electricity } \\
\hline & \multicolumn{2}{|c|}{$\begin{array}{c}\text { Hydroelectric } \\
\text { (Hydel) }\end{array}$} & \multicolumn{2}{|c|}{ Thermal } & \multicolumn{2}{|c|}{ Nuclear } & \multirow[b]{2}{*}{$\begin{array}{c}\text { Imported } \\
\text { (Gwh) }\end{array}$} \\
\hline Fiscal Year & $\begin{array}{c}\text { Installed } \\
\text { Capacity } \\
\text { (MW) a } \\
\end{array}$ & $\begin{array}{l}\text { Generation } \\
\text { (Gwh) b }\end{array}$ & $\begin{array}{c}\text { Installed } \\
\text { Capacity } \\
\text { (MW) a }\end{array}$ & $\begin{array}{l}\text { Generation } \\
\text { (Gwh) b }\end{array}$ & $\begin{array}{c}\text { Installed } \\
\text { Capacity } \\
\text { (MW) a }\end{array}$ & $\begin{array}{c}\text { Generation } \\
\text { (Gwh) b }\end{array}$ & \\
\hline $1990 / 91$ & 2,898 & 18,343 & 5,741 & 22,354 & 137 & 385 & \\
\hline $1991 / 92$ & 3,330 & 18,647 & 5,902 & 26,375 & 137 & 418 & \\
\hline $1992 / 93$ & 4,626 & 21,112 & 5,823 & 27,075 & 137 & 582 & \\
\hline $1993 / 94$ & 4,726 & 19,436 & 6,456 & 30,707 & 137 & 497 & \\
\hline $1994 / 95$ & 4,826 & 22,858 & 7,137 & 30,176 & 137 & 511 & \\
\hline $1995 / 96$ & 4,826 & 23,206 & 8,006 & 33,257 & 137 & 483 & \\
\hline $1996 / 97$ & 4,826 & 20,858 & 9,855 & 37,921 & 137 & 346 & \\
\hline $1997 / 98$ & 4,826 & 22,060 & 10,696 & 39,669 & 137 & 375 & \\
\hline $1998 / 99$ & 4,826 & 22,449 & 10,700 & 42,669 & 137 & 284 & \\
\hline $1999 / 2000$ & 4,826 & 19,288 & 12,436 & 46,064 & 137 & 399 & \\
\hline $2000 / 01$ & 4,857 & 17,194 & 12,169 & 48,926 & 462 & 1,997 & \\
\hline $2001 / 02$ & 5,041 & 18,941 & 12,286 & 51,174 & 462 & 2,291 & \\
\hline $2002 / 03$ & 5,041 & 22,351 & 12,285 & 51,591 & 462 & 1,740 & 0 \\
\hline $2003 / 04$ & 6,491 & 26,944 & 12,299 & 52,122 & 462 & 1,760 & 73 \\
\hline $2004 / 05$ & 6,494 & 25,671 & 12,423 & 57,162 & 462 & 2,795 & 109 \\
\hline $2005 / 06$ & 6,499 & 30,862 & 12,489 & 60,283 & 462 & 2,484 & 146 \\
\hline $2006 / 07$ & 6,479 & 31,953 & 12,478 & 63,972 & 462 & 2,288 & 171 \\
\hline $2007 / 08$ & 6,480 & 28,707 & 12,478 & 63,877 & 462 & 3,077 & 199 \\
\hline \multicolumn{8}{|l|}{ Jul-March } \\
\hline $2007 / 08$ & 6,482 & 21,640 & 12,412 & 49,825 & 462 & 2,319 & 202 \\
\hline $2008 / 09$ & 6,481 & 20,526 & $12,632 \mathrm{p}$ & $39154 \mathrm{p}$ & 462 & 918 & 195 \\
\hline
\end{tabular}

Source: Hydrocarbon Development Institute of Pakistan (HDIP). 
Figure-1: Pakistan-Electricity Generation

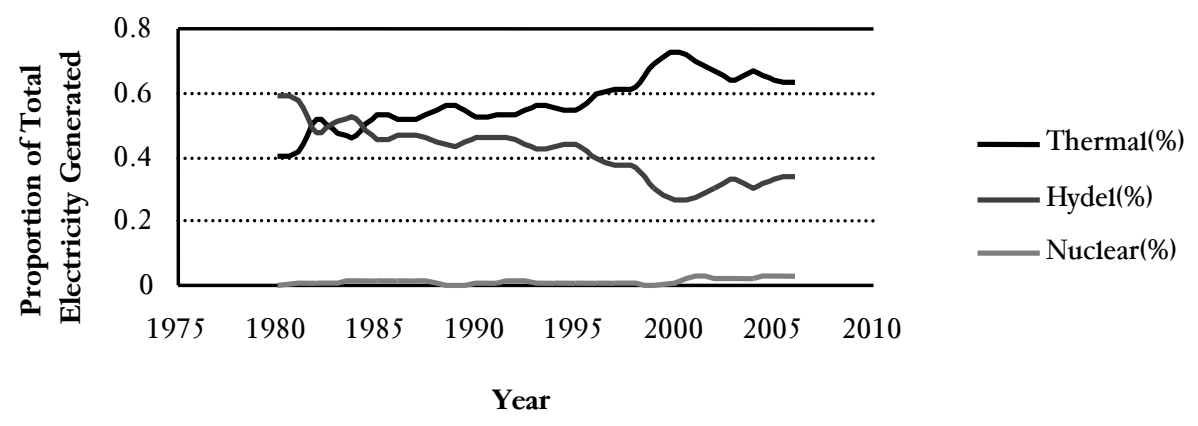

Source: International Energy Agency (2009).

Figure-2: India-Electricity Generation

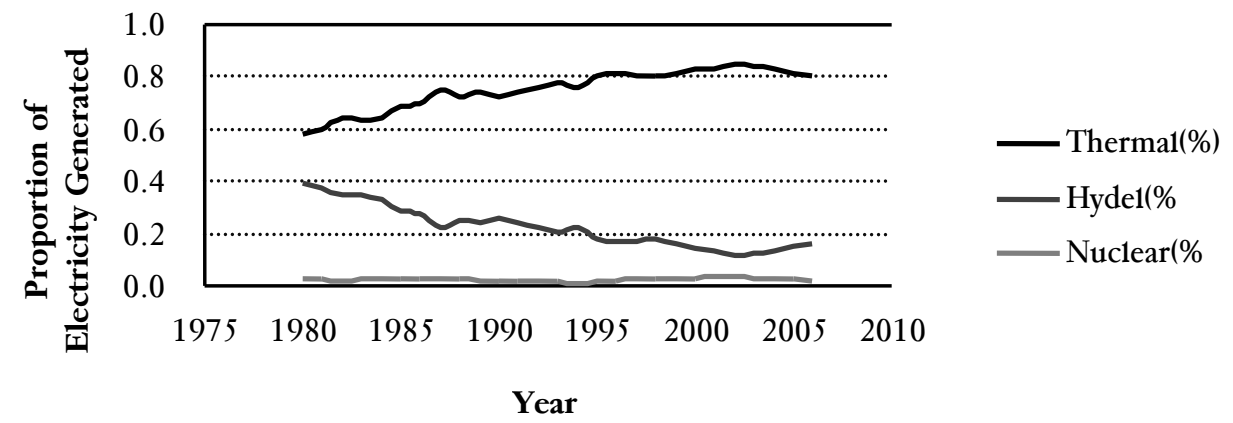

Source: International Energy Agency (2009).

Figure-3: China-Electricity Generation

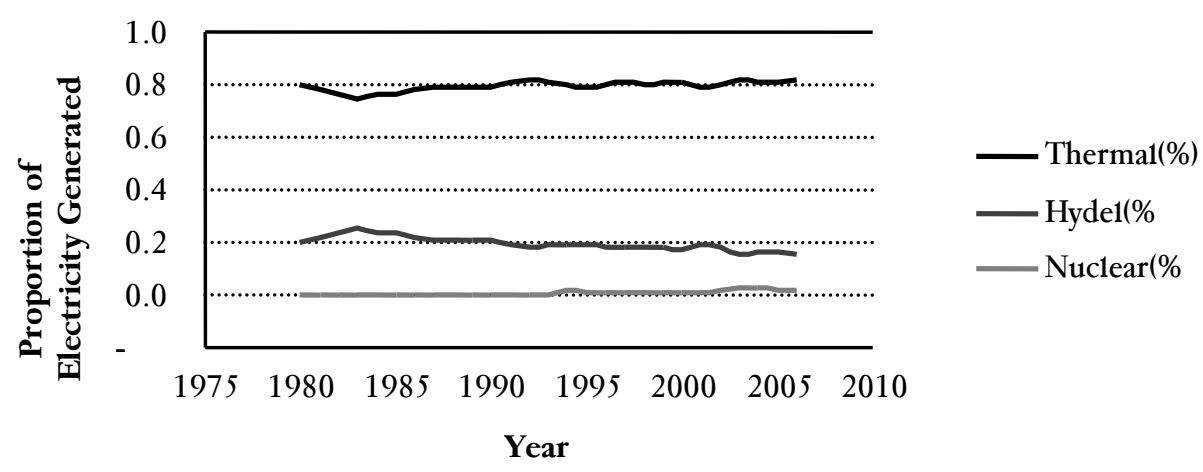

Source: International Energy Agency (2009). 
Figure-4: Energy Consumption in Pakistan

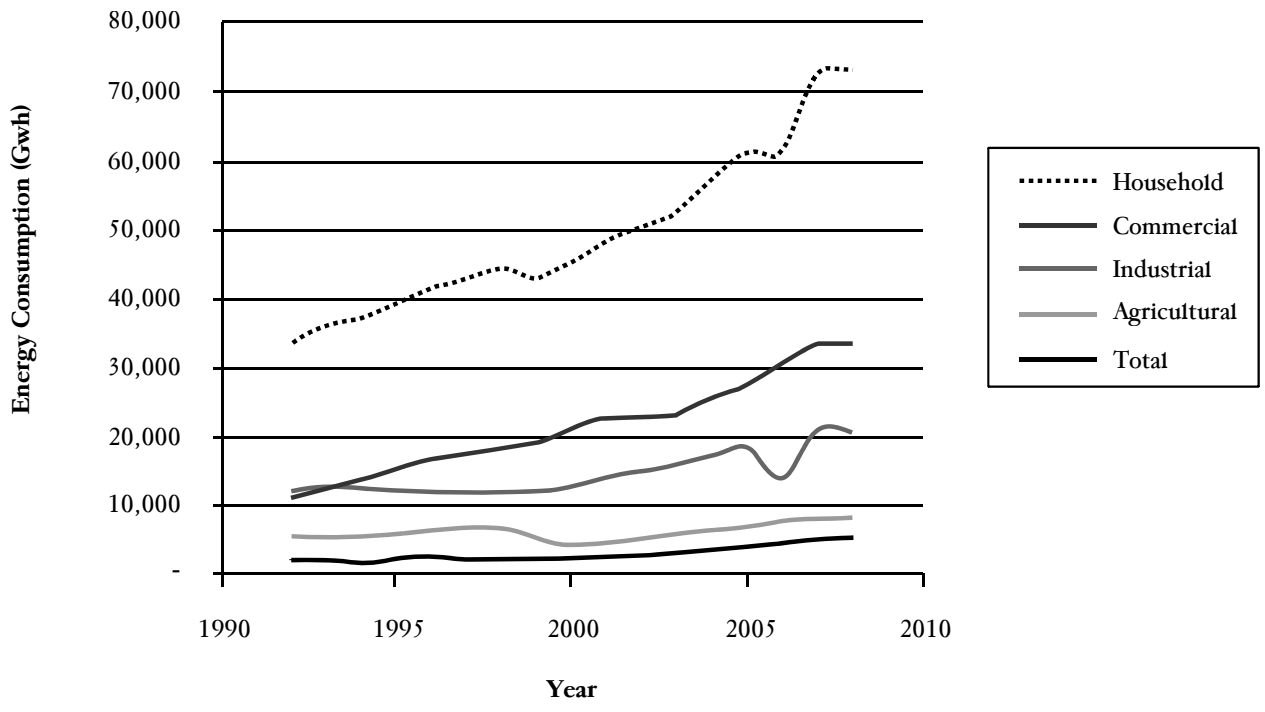

Source: Pakistan Economic Survey (various years).

Figure 4 shows the history of energy consumption in Pakistan and shows the higher rate of growth in the demand for household electricity as compared to the demand for electricity in other sectors. The rate of growth of demand for electricity in the industrial sector (despite a dip in 2005) increased after 2000 and is higher than the growth in demand in the agricultural and commercial sectors.

Figures 5 and 6 show the price of electricity in the household and industrial sectors of Pakistan, based on the most common tariff categories. ${ }^{1}$ Note that in rupee terms, the price of electricity has been increasing over time, while in US dollar terms, prices have stabilized. As a point of comparison, the price of electricity in India for households falls roughly into the range of $\$ 0.065-0.075$ and the price of electricity in India for industries falls roughly into the range of \$0.085-0.092 (Government of India, 2009).

\footnotetext{
${ }^{1}$ Note that this is not the average price across all tariff categories, but rather the average price of electricity in each sector based on the tariff categories into which most household and industrial consumers fall.
} 
Figure-5: Price of Electricity Based on Most Common Tariff Categories (Rs/KWh)

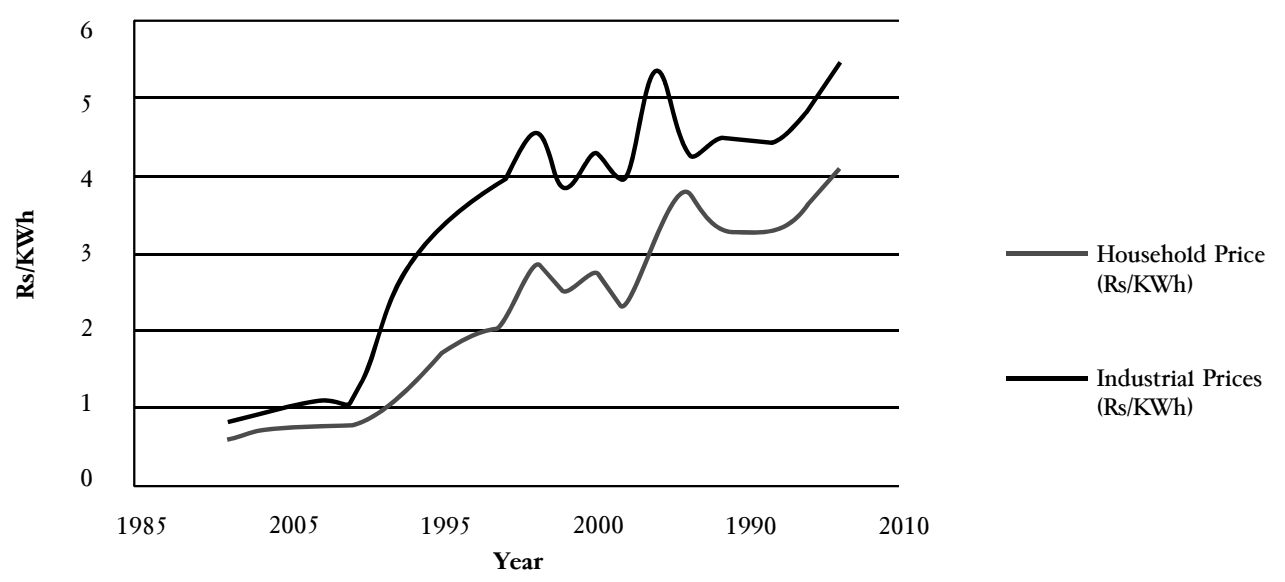

Source: Pakistan Economic Survey (various years).

Note: The prices are estimated based on the tariff categories into which households (Tier 3:101-300 units) and industries (Category B2) most commonly fall.

Figure-6: Price of Electricty Nased on Most Common Tariff Categories (\$/KWh)

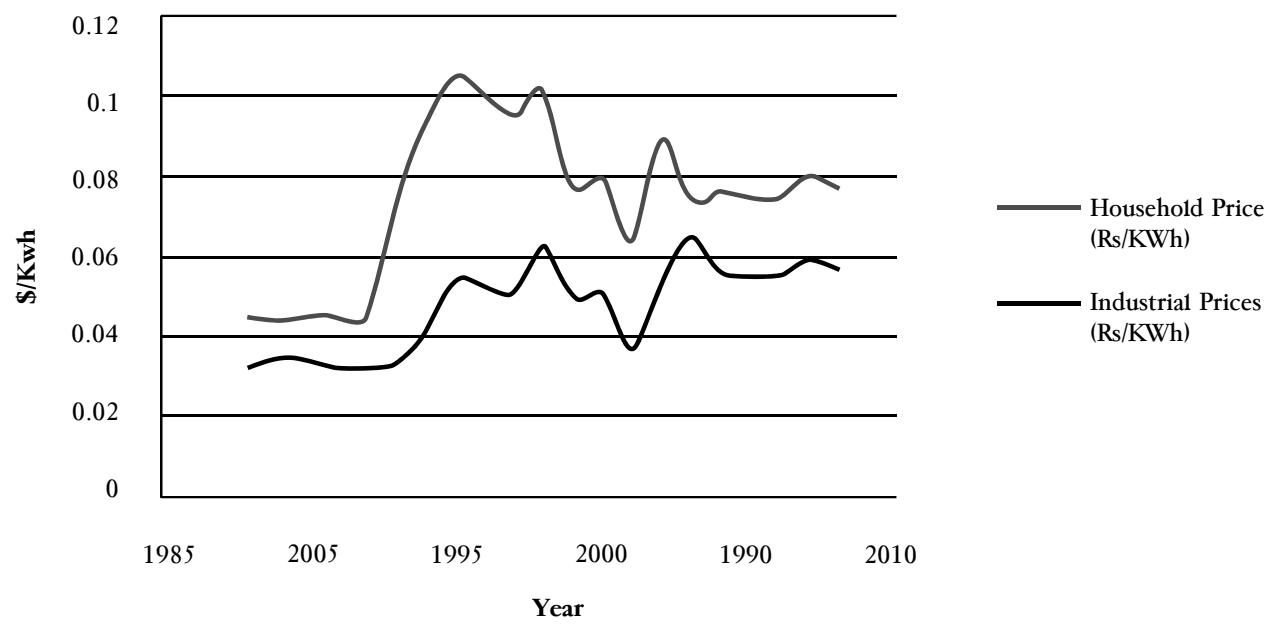

Source: Pakistan Economic Survey (various years).

Note: Prices are estimated based on the tariff categories into which households (Tier 3:101300 units) and industries (Category B2) most commonly fall. The exchange rate used is the average yearly exchange rate.

Figures 7 an 8 shows the relationship of the average price of electricity over the period 1998-2009 and the real gross domestic product 
(GDP) per capita for a sample of 63 countries. ${ }^{2}$ The interesting fact that arises is that, across countries, there is a weak positive relationship between average household electricity prices and real income, but a weakly negative relationship between average industrial household electricity prices and real income. So as real income grows in a country, household electricity prices rise but industrial electricity prices do not.

\section{Figure-7: Average Price of Electricity for Household Across Countries} (Using Averages from 1998-2008)

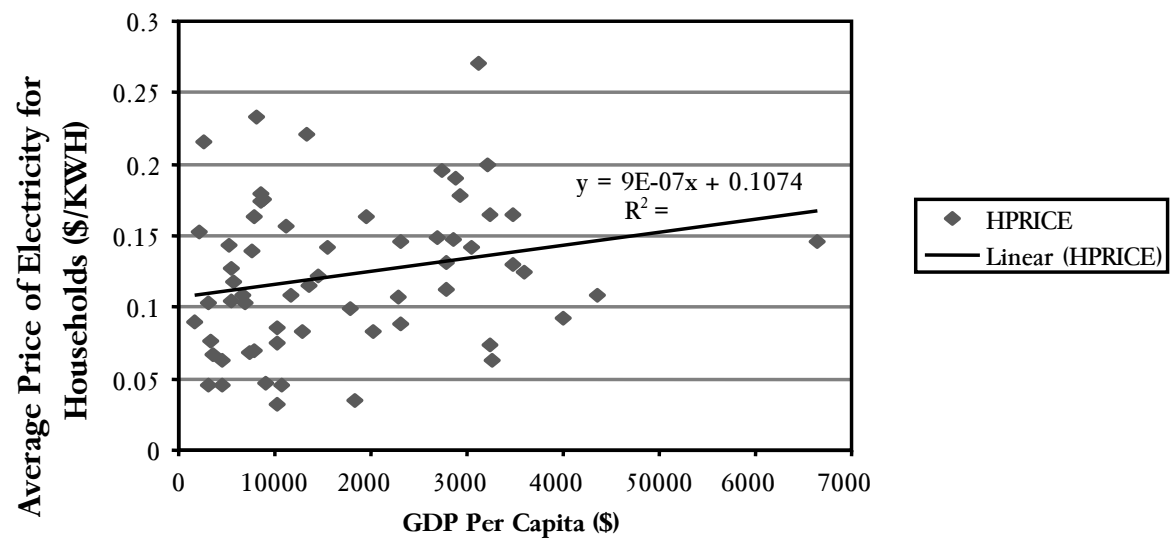

Source: International Energy Agency (2009) and Heston, Summers and Aten (2009).

\section{Figure-8: Average Price of Electricity for Industries Across Countries} (Using Averages from 1998-2008)

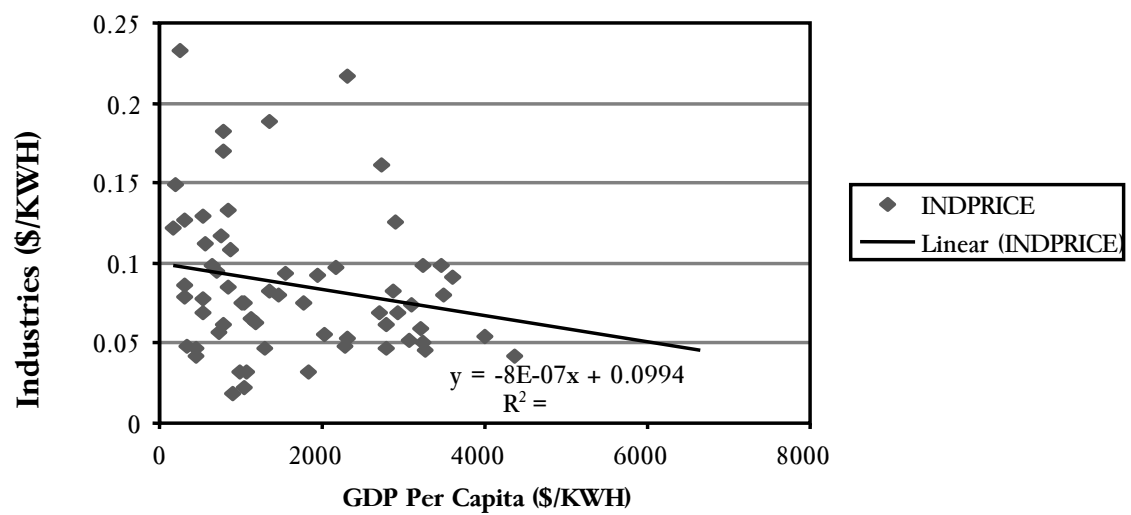

Source: International Energy Agency (2009) and Heston, Summers and Aten (2009).

\footnotetext{
${ }^{2}$ Note that these are simply nominal prices taken from the International Energy Agency.
} 


\section{Cross-Country Analysis of Demand for Electricity}

Economists and policymakers are concerned not only with the impact of electricity shortages on consumers and industries, but also with determining the potential gap between electricity supply and electricity demand in the future. While policymakers struggle with fulfilling the current level of demand, it would be a critical mistake to try and aim toward the target of energy consumption today. Rather, they should be formulating a strategy to meet potential energy demand in the next 4 to 5 years.

The purpose of this section is to look at cross-country evidence to determine what happens to the total demand for electricity as per capita GDP increases. Using a unique panel dataset with 66 countries, the elasticity of electricity consumption with respect to per capita income is calculated.

Figure 9 and Figure 10 show total electricity consumption and electricity consumption per capita in five countries (China, Indonesia, India, South Korea, and Pakistan). As can be seen, there has been a dramatic increase in total electricity consumption in China, while increases in energy consumption in the other four countries have occurred at a constant rate. Per capita consumption of electricity is far more revealing: China and South Korea have had dramatic increases in their per capita consumption (primarily due to increases in industrial output and demand), while per capita consumption in Pakistan, India, and Indonesia have grown at about the same rate.

Figure-9: Consumption of Electricity in a subsample of Countries (Billion KWh)

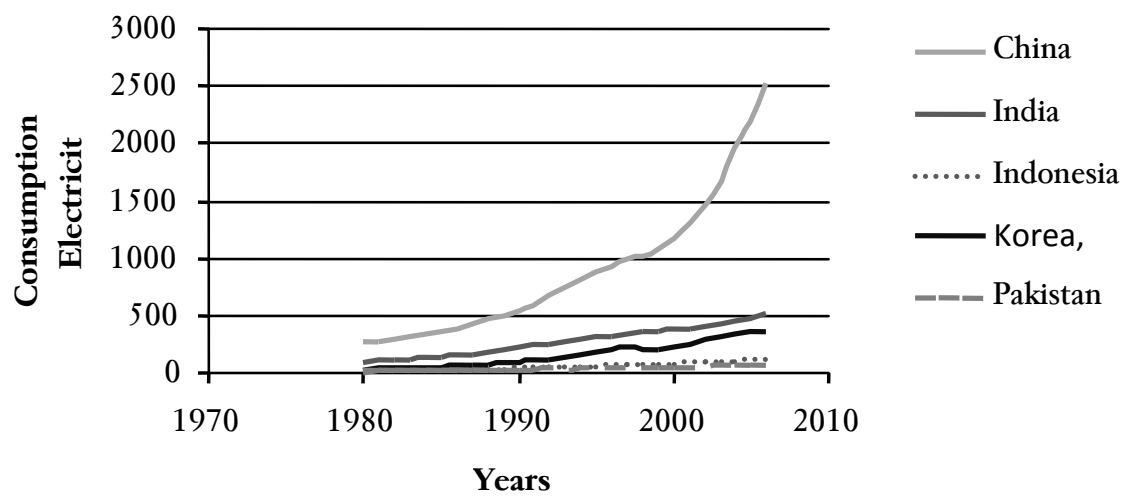


Figure-10: Consumption of Electricity per Capita in a Subsample of Countries (KWh)

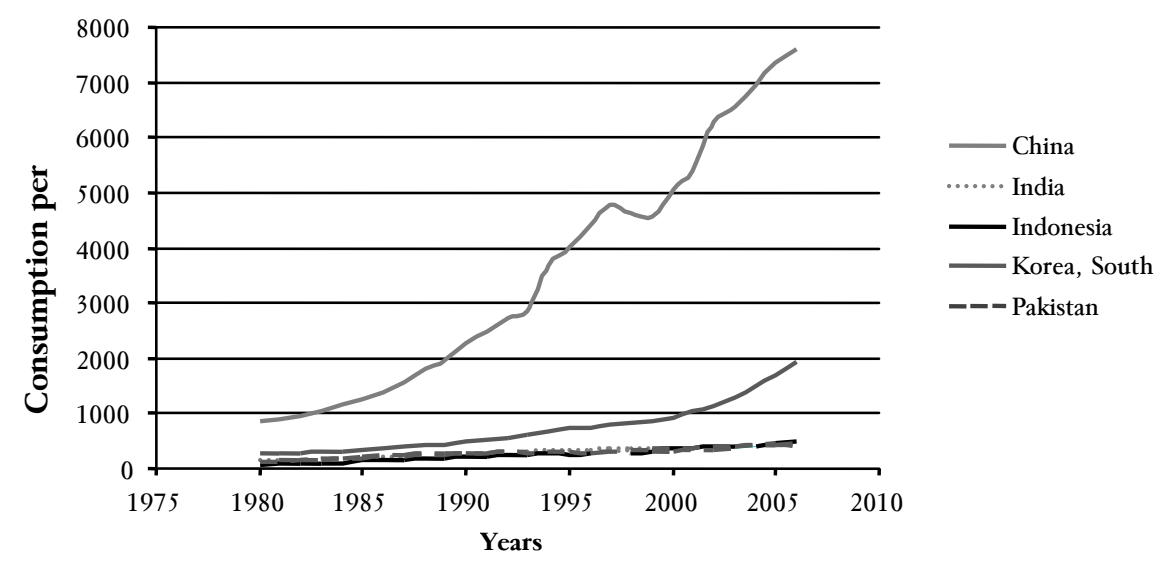

Source: International Energy Agency (2009).

Figure 3 shows average per capita consumption of electricity for a group of countries. In it, one can see that for the period 1998-2008, countries with higher real per capita GDP had higher levels of electricity consumption per capita. The fact that one has data for 66 countries across a period of 10 years $^{3}$ means that one can use a simple fixed effects model to estimate the elasticity of electricity consumption per capita with respect to per capita income.

\footnotetext{
${ }^{3}$ It should be noted at this stage that the data from the International Energy Agency did not contain consumption and price data for all years for each country and thus the panel is unbalanced.
} 


\section{Figure-11: Consumption Per Capita of Electricity Across Countries} (Average 1998-2008)

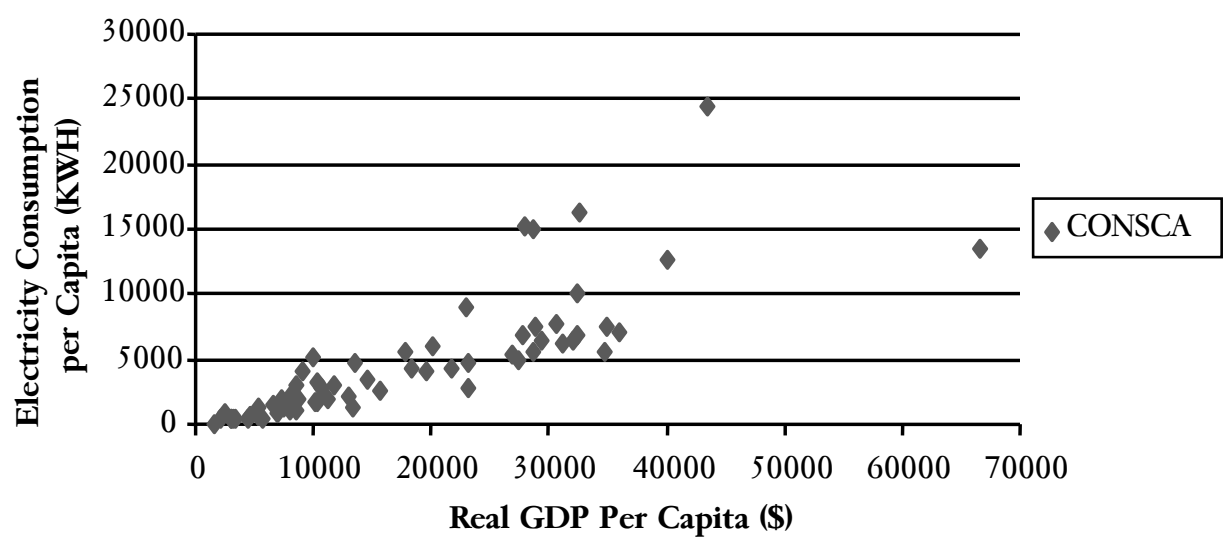

Source: International Energy Agency (2009) and Heston, Summers and Aten (2009).

\section{Econometric Model}

The basic formulation used to look at the relationship between per capita consumption of electricity, real per capita income and electricity prices is as follows:

$$
\text { elect }_{i t}=\beta_{1} \text { pcincome }_{i t}+\beta_{2} \text { prelect }_{i t}+\eta_{i}+\varepsilon_{i t}
$$

where:

elect $_{i t}$ is the per capita consumption of electricity in country $i$ at time $t$, pcincome $_{i t}$ is the real per capita income of country $\mathrm{i}$ in time $\mathrm{t}$, prelect $_{i t}$ is the average price of electricity in country $i$ in time $t$,

$\eta_{i}$ is the time invariant country specific effect that may be interpreted as the state of technology in country $i$ or level of natural resources, and

$\varepsilon_{i t}$ is the idiosyncratic error term that is uncorrelated with the explanatory variables.

The fixed effects (or within groups) estimator is based on the transformed equation in which the country specific effect is eliminated:

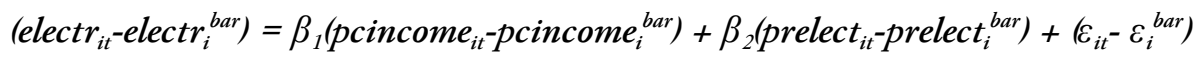


Under the assumption of exogeneity of explanatory variables, the fixed effects estimators give unbiased estimates of the elasticity of electricity consumption per capita with respect to real per capita income and electricity prices.

\section{Description of the Data}

The data used is in this analysis is taken from the International Energy Agency's (IEA) Energy Prices and Taxes, Quarterly Statistics ( $^{\text {rd }}$ Quarter, 2009). The IEA report contains data on economy-wide electricity consumption and average household and industrial electricity prices for 66 countries for the period 1998-2008. Data on population and real per capita GDP is taken from the Penn World Tables (Heston, Summers and Aten, 2009). Excluding missing data, a panel with 63 countries over a 10-year period is formed.

\section{Empirical Results}

The results of the fixed effects estimation are shown in Table-1. They show that the elasticity of per capita demand for electricity with respect to per capita income is approximately 0.69 . This means that a $5 \%$ increase in per capital income in Pakistan will be accompanied by a $3.5 \%$ increase in the demand for electricity per capita in Pakistan. As a simple, back-of-the-envelope calculation, if real GDP growth is approximately 5\% per year for 5 years and population growth is approximately $2 \%$ per year, then electricity demand will increase by approximately $9 \%$. So if policymakers are looking at projects to meet the current energy shortfall and these projects come on line in about 5 years, they should be looking to meet both current electricity demand plus another $9 \%$. 
Table-1: Estimates of Per Capita Demand for Electricity for All Countries

\begin{tabular}{lcc}
\hline \multicolumn{1}{c}{ Model } & Pooled Cross-Section & Fixed Effects \\
\hline Log(GDP Per Capita) & $1.282^{* *}$ & $0.687^{* *}$ \\
& $(.026)$ & $(.104)$ \\
$\log ($ Price) & $-0.325^{* *}$ & .012 \\
& $(.037)$ & $(.025)$ \\
Constant & $-5.042^{* *}$ & 1.59 \\
& $(.297)$ & $(1.04)$ \\
Number of Countries & 63 & 63 \\
$\mathrm{R}^{2}$ & 0.875 & 0.843 \\
$\mathrm{R}^{2}$ within & & 0.616 \\
Parameters & 2 & 2 \\
Observations & 344 & 344 \\
\hline
\end{tabular}

*Significant at $10 \%$ leve1. **Significant at $1 \%$ level.

Before one moves on, one may want to consider the possibility that low- and middle-income countries have a greater elasticity of electricity consumption than higher-income countries, because low- and middleincome countries may be in the process of rapid industrialization which could have a significant impact on their consumption per capita. The analysis above was also performed for low- and middle-income countries (based on the World Bank definition of low- and middle-income countries) and the results are shown below. As can be seen, the elasticity of electricity consumption with respect to income per capita is not significantly different from the estimates for the entire sample. 
Table-2: Estimates of Per Capita Demand for Electricity for Low and Middle Income Countries

\begin{tabular}{lcc}
\hline \multicolumn{1}{c}{ Model } & Pooled Cross-Section & Fixed Effects \\
\hline Log(GDP Per Capita) & $1.62^{* *}$ & $0.65^{* *}$ \\
& $(0.083)$ & $(0.113)$ \\
$\log ($ Price $)$ & $-.212^{* *}$ & 0.036 \\
& $(0.057)$ & $(0.033)$ \\
Constant & $-7.60^{* *}$ & 1.52 \\
& $(0 . .73)$ & $(0.993)$ \\
Number of Countries & 28 & 28 \\
$\mathrm{R}^{2}$ & 0.784 & 0.732 \\
$\mathrm{R}^{2}$ within & & 0.695 \\
Parameters & 2 & 2 \\
Observations & 117 & 117 \\
\hline
\end{tabular}

*Significant at $10 \%$ level. **Significant at $1 \%$ level.

\section{Micro Level Analysis of Demand for Electricity in the Industrial Sector of Pakistan}

Over the last decade, policymakers, economists, and businessmen have increasingly concerned themselves with the demand by the household and manufacturing sectors for electricity. As the price of electricity facing both households and firms has increased, the question of the impact of higher electricity prices on standards of living and on manufacturing output has become critical from both a welfare perspective and an economic growth perspective. The purpose of this section is to use firm-level data to determine the elasticity of manufacturing output with respect to the price of industrial electricity.

Most analyses of the demand for electricity use time series data and macroeconometric tools to look at the response of economy-wide demand for electricity (or the demand for electricity by a particular sector, such as the household or manufacturing sector) to changes in the price of electricity. Over the last decade, the availability of better quality disaggregated data has enabled researchers to begin focusing on micro-leve1 analyses of the demand for electricity, with an emphasis on either household demand for electricity or firm-level demand for electricity.

At the firm level, a few studies such as Woodland (1993) and Bjorner et a1. (2001) use panel data on firms to see the impact of changes in the 
prices of electricity on firm-level output. The main benefit of a panel data set is that it allows one to relax the strict assumptions about the uniformity of the estimated parameters. The analysis in this section uses a relatively new panel data set containing data on 402 firms over 4 different years to determine the impact of changes in the price of industrial electricity on the demand for electricity by Pakistani manufacturing firms. Using this data, a fixed effects model is estimated for all 402 firms to find the aggregate elasticity of electricity demand with respect to price. This is followed by a disaggregated analysis in which the firms are divided according to subsector to determine each subsector's specific price elasticity of demand. The subsectors analyzed are the textile sector, the food sector, the chemical sector, the leather sector, and a final sector that combines the electronics and other manufacturing sectors.

\section{Microeconomic Foundations of Estimated Model}

For firms, electricity is used as an input in their production functions. If one makes the assumption that firms consider the price of electricity and other factors of production to be exogenous and that each firm minimizes its cost function, the demand function can be simply expressed as a function of the factors of production and the level of production (Bjorner, 2001). Thus the firm's short-term problem of minimizing production costs can be expressed as:

$$
C(p, y)=\operatorname{Min}\left(p_{1} x_{1}+\ldots p_{n} x_{n}\right)
$$

s.t.

$f\left(x_{1}, \ldots, x_{n}\right) \geq y$ and $\left(x_{1}, \ldots, x_{n}\right) \geq 0$

where $\left(p_{1}+\ldots p_{n}\right)$ are given factor prices for the $\mathrm{n}$ inputs, $\left(x_{1}, \ldots, x_{n}\right)$ are the quantities of of the $\mathrm{n}$ inputs used, $\mathrm{y}$ is the level of output and $f\left(x_{1}, \ldots, x_{n}\right)$ is the production function indicating the feasible output.

Shephard's Lemma yields the factor demand functions $X_{i}(p, y)$ :

$$
X_{i}(p, y)=\partial C(p, y) / \partial p_{i} \quad i=1, \ldots, n
$$

So the demand for electricity can be expressed as:

$$
E=f\left(p_{e}, p_{o t h e r}, y\right)
$$

where $\mathrm{E}$ is electricity demand, $\mathrm{p}_{\mathrm{e}}$ is the price of electricity, $\mathrm{p}_{\text {other }}$ is the prices of the other factors of production and $y$ is the level of output. 
If one makes the assumption that electricity is separable from other inputs so that the relationship between electricity with other inputs is neutral in terms of price, it is possible to exclude the price of other inputs from the model.

\section{Econometric Model}

When deciding the function form, one finds that there is very little consensus about the 'correct' functional form, although most studies use either a linear or a logarithmic form. In this paper, a simple log linear form is adopted, similar to Bjorner et al (2001):

$$
\begin{aligned}
& L E_{i t}=\alpha_{i}+\beta_{1} L F Y_{i t}+\beta_{2} L P E_{i t}+\lambda_{t}+v_{i t} \\
& v_{i t} \sim \text { i.i.d N }\left(0, \sigma_{v}{ }^{2} I\right)
\end{aligned}
$$

where $\mathrm{LE}_{\mathrm{it}}$ is the $\log$ of electricity consumption in time $\mathrm{t}$ for the ith firm measured in KWH, $\mathrm{LFY}_{\mathrm{it}}$ is the $\log$ of yearly output in rupees in time $\mathrm{t}$ of firm $i$ adjusted by a price deflator for output, and $L P E_{i t}$ is the average price of electricity faced by firm $i$ in time $t$, also adjusted by a price deflator. The parameter $\beta_{1}$ measures the elasticity of electricity demand with respect to output and the parameter $\beta_{2}$ measures the elasticity of electricity demand with respect to electricity price.

In the model above, it is assumed that all parameters are equal across firms, except for $\alpha_{i}$, which captures all unobservable heterogeneous company-level variables that affect electricity demand, such as management ability, sector of production, etc. The parameter $\lambda_{t}$ captures the effect of changes in unobserved variables that influence companies equally, such as technological changes, temperature, government policies, etc.

Similar to the estimators from the last section, the fixed effects estimators are derived as follows:

$$
\left(L E_{i t}-L E_{i}^{b a r}\right)=\beta_{1}\left(L F Y_{i t}-L F Y_{i}^{b a r}\right)+\beta_{2}\left(L P E_{i t}-L P E_{i}^{b a r}\right)+\left(v_{i t}-v_{i}^{b a r}\right)
$$

where the subscript, bar, represents the average variable for country $i$ across time.

It should be noted that the simple model above assumes that the parameters measuring elasticities of electricity demand with respect to output and prices are assumed to be the same across all firms. In actuality, it is much more likely that the elasticities will vary across industries because 
different types of companies respond in different ways to changes in output and changes in electricity prices. For this reason, the model above is also estimated for the following industrial subsectors: the textile sector, the food sector, the chemicals sector, the leather sector, and a final sector that combines the electronics and other manufacturing sectors.

\section{Description of the Data}

The data is taken primarily from two sources: Firm-level data on annual output, and annual electricity expenditures are taken from the World Bank's Enterprise Surveys, 2002 and 2006/07 while data on industrial electricity tariff structures is taken from the Economic Survey of Pakistan.

The World Bank Enterprise Survey (conducted as a part of the World Bank's Investment Climate Assessment for Pakistan) was administered twice in Pakistan, in 2002 and 2006/07. The firm-level surveys were conducted for a representative sample of firms in the private sector, focused on the manufacturing sector, and were answered by business owners and top managers. The Enterprise Survey conducted in Pakistan gathered information on firm-level characteristics, annual sales of firms, costs of inputs and labor, and indicators of business environment. There were a total of 402 firms for which data was collected in both surveys.

For the purposes of the analysis in this section, firm-level data was taken for the value of annual output and annual expenditures on electricity. An extremely useful fact of the survey was that it not only collected data for the year of the surveys (2002 and 2006/07), but also collected some (though not all) data for the 'previous year'. One could thus gather firm-level data on firm-level characteristics, annual sales, and expenditures on electricity for 4 years $(2001,2002,2005 / 06$ and 2006/07). Thus, one was able to construct a panel dataset for 402 firms for a period of 4 years.

The Economic Survey of Pakistan was used to calculate the average price of electricity faced by each firm. Since the firm-level surveys only had data on annual expenditures on electricity, the following procedure was adopted to calculate an 'average price of electricity' facing each firm: For each of the years of the survey, the tariff structure for industrial electricity was taken from the Economic Survey of Pakistan. Then for each category of industrial electricity consumers (B2, B3, and B4), a range was created into which the annual expenditure on electricity would fit. Based on these ranges, each of the 402 firms was placed in a tariff category. After this, the tariff structure was again used to calculate an average price of electricity in $\mathrm{Rs} / \mathrm{kWH}$ for each tariff category, based on average annual usage of 
electricity. This average price was then used in conjunction with the firmlevel data on annual expenditures on electricity to calculate the consumption of electricity for each firm (in $\mathrm{kWH}$ ).

From these two sources, one obtained data on annual electricity consumption $\mathrm{E}_{\mathrm{it}}$ (in $\mathrm{kWH}$ ), annual output $\mathrm{FY}_{\text {it }}$ (in rupees) and annual average price of electricity $\mathrm{PE}_{\mathrm{it}}$ (in Rs/kWH) for each of the 402 firms for 4 years. In order to estimate the log-linear form of the electricity demand function (described above), natural logs were taken of the variables to obtain $L_{\mathrm{it}}$, $\mathrm{LFY}_{\mathrm{it}}$, and $\mathrm{LPE}_{\mathrm{it}}$.

\section{Empirical Results}

The results for the sample of firms is given in Table-3, which shows both the pooled OLS estimates and the fixed effects estimates. As the results show, the price elasticity of electricity demand across the sample of firms is -0.57 and the output elasticity of the demand for electricity is 0.194 . The results imply that a $10 \%$ increase in the price of industrial electricity will lead to a $5.7 \%$ decrease in the demand for electricity, making the demand for elasticity relatively inelastic with respect to price. Also, a $10 \%$ increase in firm level output will lead to a $1.9 \%$ increase in the demand for electricity.

The results for the estimation of the model for the subsamples according to sector is given in Table-4. As the results show, the textile sector has the highest price elasticity of demand for electricity $(-0.81)$ which is significantly higher than the mean price elasticity discussed. Also, the demand for electricity in the food sector is more elastic with respect to price $(-0.67)$ than the average firm. The only other significant result is that the price elasticity of demand for electricity in the electronics and other manufacturing sector is equal to -0.31 , while the other price elasticities (for the chemical and leather subsectors) are insignificant.

Although the price elasticities are all less than 1, they are higher than estimates obtained from similar studies in other countries. Bjorner et a1. (2001) found price elasticities in the range of -0.4 to 0.06 across Danish industrial subsectors. Woodland (1993) found price elasticities greater than 1 for a sample of Australian firms, although he chose firms that used coal, oil, gas, and electricity which would allow firms to switch away for electricity as an input when faced with higher prices.

The results could imply two things: First, if the textile and food sectors are the ones with the most private electricity generating capacity 
(generators), then they would be able to reduce their demand for external electricity the most easily, although switching the own-generated electricity may substantially increase their costs. ${ }^{4}$ Second, if the firms in these sectors are not all generating their own electricity, then their overall electricity usage (and overall output) is most susceptible to increases in electricity prices. It is important to understand the implications of higher industrial electricity prices in both cases.

Table-3: Estimates of Electricity Demand Function for All Firms

\begin{tabular}{lcc}
\hline Model & Pooled Cross-Section & Fixed Effects \\
\hline Log(Output) & $0.297^{* *}$ & $0.194^{* *}$ \\
& $(0.007)$ & $(0.017)$ \\
$\log$ ( Price) & $-0.552^{* *}$ & $-0.574^{* *}$ \\
& $(0.086)$ & $(0.107)$ \\
Constant & $0.942^{* *}$ & $2.69^{* *}$ \\
& $(0.17)$ & $(0.332)$ \\
Number of Firms & 399 & 399 \\
$\mathrm{R}^{2}$ & 0.5624 & 0.5583 \\
$\mathrm{R}^{2}$ within & & 0.27 \\
Parameters & 2 & 2 \\
Observations & 1467 & 1467 \\
\hline
\end{tabular}

*Significant at $10 \%$ level. **Significant at $1 \%$ level.

\footnotetext{
${ }^{4}$ The question would be far easier to answer if the question on electricity expenditures in the Enterprise Survey had separated out expenditures on outside electricity and expenditures on own-generated electricity. Unfortunately, this distinction was not made clear in the survey.
} 
Table-4: Estimates of Demand Function for Electricity by Industrial Subsector

\begin{tabular}{|c|c|c|c|}
\hline Industrial Sub-Sector & Model & $\begin{array}{c}\text { Pooled Cross- } \\
\text { Section } \\
\end{array}$ & Fixed Effects \\
\hline \multicolumn{4}{|l|}{ Textiles } \\
\hline & Log(Output) & $\begin{array}{l}0.327^{* * *} \\
(0.011)\end{array}$ & $\begin{array}{l}0.215^{* *} \\
(0.026)\end{array}$ \\
\hline & Log( Price) & $\begin{array}{l}-0.808^{* *} \\
(0.132)\end{array}$ & $\begin{array}{l}-0.807^{* *} \\
(0.167)\end{array}$ \\
\hline & Constant & $\begin{array}{l}0.912 * * \\
(0.263)\end{array}$ & $\begin{array}{l}2.788 * * \\
(0.492)\end{array}$ \\
\hline & Number of Firms & 176 & 176 \\
\hline & $\mathrm{R}^{2}$ & 0.615 & 0.609 \\
\hline & $\mathrm{R}^{2}$ within & & 0.310 \\
\hline & Parameters & 2 & 2 \\
\hline & Observations & 643 & 643 \\
\hline \multicolumn{4}{|l|}{ Food } \\
\hline & Log(Output) & $\begin{array}{l}0.220^{* *} \\
(0.018)\end{array}$ & $\begin{array}{l}0.196^{* *} \\
(0.048)\end{array}$ \\
\hline & Log( Price) & $\begin{array}{l}-0.609 * * \\
(0.207)\end{array}$ & $\begin{array}{l}-0.671 * \\
(0.358)\end{array}$ \\
\hline & Constant & $\begin{array}{l}2.44^{* *} \\
(0.46)\end{array}$ & $\begin{array}{l}2.932 * \\
(1.177)\end{array}$ \\
\hline & Number of Firms & 62 & 62 \\
\hline & $\mathrm{R}^{2}$ & 0.457 & 0.456 \\
\hline & $\mathrm{R}^{2}$ within & & 0.350 \\
\hline & Parameters & 2 & 2 \\
\hline & Observations & 230 & 230 \\
\hline \multicolumn{4}{|l|}{ Chemicals } \\
\hline & Log(Output) & $\begin{array}{l}0.280 * * \\
(0.021)\end{array}$ & $\begin{array}{l}0.15^{*} \\
(0.063)\end{array}$ \\
\hline & Log( Price) & $\begin{array}{l}-0.030 \\
(0.248)\end{array}$ & $\begin{array}{l}0.084 \\
(0.334)\end{array}$ \\
\hline & Constant & $\begin{array}{l}0.383 \\
(0.519)\end{array}$ & $\begin{array}{l}2.478^{*} \\
(1.17)\end{array}$ \\
\hline & Number of Firms & 45 & 45 \\
\hline & $\mathrm{R}^{2}$ & 0.522 & 0.524 \\
\hline
\end{tabular}




$\begin{array}{lll}\mathrm{R}^{2} \text { within } & & 0.1313 \\ \text { Parameters } & 2 & 2 \\ \text { Observations } & 159 & 159\end{array}$

\section{Leather}

$\begin{array}{lll}\text { Log(Output) } & \begin{array}{l}0.272^{* *} \\ (0.026)\end{array} & \begin{array}{l}0.122^{*} \\ (0.048)\end{array} \\ \text { Log( Price) } & 0.038 & -0.271 \\ & (0.283) & (0.273) \\ \text { Constant } & 0.289 & 3.12^{* *} \\ & (0.567) & (0.862) \\ \text { Number of Firms } & 25 & 25 \\ \mathrm{R}^{2} & 0.546 & 0.187 \\ \mathrm{R}^{2} \text { within } & & 0.187 \\ \text { Parameters } & 2 & 2 \\ \text { Observations } & 94 & 94\end{array}$

Electronics, Machinery and other Manufacturing

$\begin{array}{lll}\log \text { (Output) } & 0.243^{* *} & 0.141^{* *} \\ & (0.014) & (0.039) \\ \log (\text { Price) } & -0.366^{*} & -0.31^{*} \\ & (0.162) & (0.182) \\ \text { Constant } & 1.394^{* *} & 2.95^{* *} \\ & (0.300) & (0.660) \\ \text { Number of Firms } & 83 & 83 \\ \mathrm{R}^{2} & 0.489 & 0.487 \\ \mathrm{R}^{2} \text { within } & & 0.12 \\ \text { Parameters } & 2 & 2 \\ \text { Observations } & 311 & 311\end{array}$

*Significant at $10 \%$ leve1. **Significant at $1 \%$ level.

\section{Micro-Level Analysis of the Production Functions of Pakistani Firms}

Analyses of production functions date back to the 1920s, when macro-level data was used to estimate an economy-wide production function in order to test marginal productivity theory and labor market competitiveness. In the 1960s, the emphasis shifted from macroeconomic analyses to microeconomic analyses, especially in the area of agriculture. 
Usual estimations of the production function focus on two factors of production, typically labor and capital. In more recent times, other factors of production have been included in the estimation process, ranging from land to human capital. The analysis in this section extends the normal firm level production function to include electricity.

The reason for doing this concerns the realities facing the Pakistani manufacturing sector. Unlike the other economies for which firm-level production functions (and price elasticities of electricity demand) are estimated, Pakistan faces a severe shortage of electricity which is set to continue into the indefinite future. For this reason, the estimation of a firmlevel production function with electricity as an input can give us an estimate of the elasticity of output with respect to electricity, which in turn can provide us with estimates of the impact of decreases in the amount of available electricity on manufacturing sector output.

As in the analysis in the previous section, this analysis employs the panel dataset from the World Bank's Enterprise Survey to estimate a fixed effects model of a firm-level production function. Also like the previous section, the analysis is performed for all firms in the sample, and also for firms in particular subsectors. Again, the subsectors analyzed are the textile sector, the food sector, the chemicals sector, the leather sector, and a final sector that combines the electronics and other manufacturing sectors.

\section{Econometric Model}

As discussed in Aguirregabiria (2009), there are numerous ways to estimate firm-level production functions, ranging from simple OLS to GMM estimation for dynamic panel data. This paper adopts a within-firms estimator for a Cobb-Douglas production function originally based on the work of Mundlak (1961) and Mundlach and Hoch (1965):

$$
y_{i t}=\alpha_{L} l_{i t}+\alpha_{K} k_{i t}+\alpha_{E} e_{i t}+\omega_{i t}+\varepsilon_{i t}
$$

where:

$y_{i t}$ is the $\log$ of output of firm $\mathrm{i}$ in time $\mathrm{t}$,

$l_{i t}$ is the $\log$ of labor employed in firm $\mathrm{i}$ in time $\mathrm{t}$,

$k_{i t}$ is the $\log$ of capital used by firm $\mathrm{i}$ in time $\mathrm{t}$,

$e_{i t}$ is the $\log$ of electricity usage of firm $\mathrm{i}$ in time $\mathrm{t}$, 
$\omega_{i t}=\eta_{i}+\delta_{t}+\omega_{i t}^{*}$, where $\eta_{\mathrm{i}}$ is a time invariant firm-specific effect such as the quality of a fixed input such as managerial ability, or land quality, $\delta_{t}$ is an aggregate shock affecting all firms and $\omega_{i t}{ }^{*}$ is a firm level idiosyncratic shock, and

$\varepsilon_{i t}$ an idiosyncratic error term.

Based on the assumptions that (i) idiosyncratic shocks, $\omega_{\text {it }}{ }^{*}$, are realized after the firm decides on its level of inputs, (ii) idiosyncratic shocks, $\omega_{\text {it }}{ }^{*}$, are not serially correlated, and (iii) that the amount of inputs depends on some other exogenous time varying variables, we can derive the fixed effects estimator of the production function which removes the fixed affect $\eta_{\mathrm{i}}$ :

$\left(y_{i t}-y_{i}^{b a r}\right)=\alpha_{L}\left(l_{i t}-l_{i}^{b a r}\right)+\alpha_{K}\left(k_{i t}-k_{i}^{b a r}\right)+\alpha_{E}\left(e_{i t}-e_{i}^{b a r}\right)+\left(\omega_{i t}-\omega_{i}^{b a r}\right)+\left(\varepsilon_{i t}-\varepsilon_{i}^{b a r}\right)$

\section{Description of the Data}

The firm-level dataset from the Enterprise Survey for Pakistan (and described in the last section) was used to gather firm-level data on annual output, annual amount of labor employed, annual capital stocks, and annual electricity consumption. However, unlike the dataset used in the last section, some of the data on the variables used in the estimation of the production function (1abor employed and capital stocks) were not available for the year before the survey year. Thus, for this analysis, the firm-level data for 402 firms for 2 years (2002 and 2006/07) was used. After the model is estimated for all the firms, the model is also estimated for the textile sector, the food sector, the chemicals sector, the leather sector, and a final sector that combines the electronics and other manufacturing sectors.

\section{Empirical Results}

The estimation results for the entire sample of firms are given in Table-5. The results show that the coefficient of (log) electricity in the production function is 0.502 , implying that a $10 \%$ decrease in electricity inputs can lead to a $5 \%$ decrease in industrial output. While these results are significant, they need to be viewed with caution with regard to policymaking. Since we are unsure of the external/own-generated breakup of the firms electricity inputs, one cannot simply say that if external electricity supplies fall by $10 \%$, then output falls by $5 \%$, because a $10 \%$ fall in external electricity supplies may be partially (or fully) offset by private electricity generation. So, although electricity is a critical factor of production across firms, it is difficult to predict exactly what happens to output, although one 
can be sure of shortages in external electricity supplies and increased dependence of own-generated electricity.

The estimations for different manufacturing subsectors are given in Table-6. Note that the elasticities of output with respect to electricity inputs are found to be insignificant across most industries, with the exception of the food subsector (which seems to be unrealistically high). This could be due to smaller sample sizes in each analysis (because of the smaller panel used in the analysis).

Analyzing the full sample results again show that electricity is a critical input in the production function across firms and that its elasticity of output with respect to electricity inputs is as high as that of labor, and significantly higher than the elasticity of output with respect to capital. In terms of policymaking, one has to realize that with its present levels of technology, the Pakistani manufacturing sector is heavily reliant on labor and electricity and far less on capital. Electricity shortages will either force smaller firms without own-electricity generating capacity to significantly decrease their output, or will force firms with their own electricity generating capacity to face significantly higher input prices.

Table-5: Estimates of Production Function for All Firms

\begin{tabular}{lcc}
\hline Model & Pooled Cross-Section & Fixed Effects \\
\hline Log(Capital) & $0.195^{* *}$ & $0.170^{* *}$ \\
& $(0.035)$ & $(0.075)$ \\
Log( Labor) & $0.597^{* *}$ & $0.508^{* *}$ \\
& $(0.057)$ & $(0.108)$ \\
Log(Electricity) & $0.914^{* *}$ & $0.502^{* *}$ \\
Constant & $(0.089)$ & $(0.166)$ \\
& $6.799^{* *}$ & $9.614^{* *}$ \\
Number of Firms & $(0.475)$ & $(1.29)$ \\
$\mathrm{R}^{2}$ & 386 & 386 \\
$\mathrm{R}^{2}$ within & 0.64 & 0.636 \\
Parameters & & 0.257 \\
\hline
\end{tabular}

*Significant at $10 \%$ level. **Significant at $1 \%$ level. 
Table-6: Estimates of Production Function for Firms According to SubSector

\begin{tabular}{|c|c|c|c|}
\hline Industrial Sub-Sector & Model & $\begin{array}{c}\text { Pooled Cross- } \\
\text { Section } \\
\end{array}$ & Fixed Effects \\
\hline \multicolumn{4}{|l|}{$\overline{\text { Textiles }}$} \\
\hline & \multirow[t]{2}{*}{ Log(Capita1) } & $0.217^{* *}$ & $0.159^{*}$ \\
\hline & & $(0.055)$ & $(0.091)$ \\
\hline & \multirow[t]{2}{*}{ Log( Labor) } & $0.518 * *$ & $0.523 * *$ \\
\hline & & $(0.082)$ & $(0.150)$ \\
\hline & \multirow[t]{2}{*}{ Log(Electricity) } & $0.849 * *$ & 0.299 \\
\hline & & $(0.125)$ & $(0.237)$ \\
\hline & \multirow[t]{2}{*}{ Constant } & $6.86^{* *}$ & $10.63 * *$ \\
\hline & & $(0.725)$ & $(1.63)$ \\
\hline & Number of Firms & 169 & 169 \\
\hline & $\mathrm{R}^{2}$ & 0.678 & 0.660 \\
\hline & $\mathrm{R}^{2}$ within & & 0.283 \\
\hline & Parameters & 3 & 3 \\
\hline & Observations & 248 & 248 \\
\hline \multicolumn{4}{|l|}{ Food } \\
\hline & \multirow[t]{2}{*}{ Log(Capital) } & $0.399 *$ & $0.42 * *$ \\
\hline & & $(0.082)$ & $(0.15)$ \\
\hline & \multirow[t]{2}{*}{ Log( Labor) } & $0.408^{* *}$ & 0.093 \\
\hline & & $(0.155)$ & $(0.243)$ \\
\hline & \multirow[t]{2}{*}{ Log(Electricity) } & $1.183^{* *}$ & $0.934 * *$ \\
\hline & & $(0.205)$ & $(1.152)$ \\
\hline & \multirow[t]{2}{*}{ Constant } & $2.91 *$ & 5.031 \\
\hline & & $(1.31)$ & (3.18) \\
\hline & Number of Firms & 62 & 62 \\
\hline & $\mathrm{R}^{2}$ & 0.572 & 0.554 \\
\hline & $\mathrm{R}^{2}$ within & & 0.473 \\
\hline & Parameters & 3 & 3 \\
\hline & Observations & 106 & 106 \\
\hline \multicolumn{4}{|l|}{ Chemicals } \\
\hline & \multirow[t]{2}{*}{$\log ($ Capital) } & $0.324 * *$ & $0.278^{*}$ \\
\hline & & $(0.109)$ & $(0.160)$ \\
\hline & \multirow[t]{2}{*}{$\log ($ Labor $)$} & $0.649 * *$ & $0.502 *$ \\
\hline & & $(0.157)$ & $(0.248)$ \\
\hline & \multirow[t]{2}{*}{ Log(Electricity) } & $0.613^{* *}$ & 0.03 \\
\hline & & $(0.261)$ & $(0.428)$ \\
\hline & \multirow[t]{2}{*}{ Constant } & $6.19^{* *}$ & $10.61 * *$ \\
\hline & & $(1.42)$ & $(2.01)$ \\
\hline
\end{tabular}




\section{Leather}

$\begin{array}{lll}\text { Number of Firms } & 43 & 43 \\ \mathrm{R}^{2} & 0.693 & 0.685 \\ \mathrm{R}^{2} \text { within } & & 0.284 \\ \text { Parameters } & 3 & 3 \\ \text { Observations } & 70 & 70\end{array}$

$\begin{array}{lll}\text { Log(Capital) } & 0.024 & 0.035 \\ & (0.291) & (0.102) \\ \text { Log( Labor) } & 0.330 & 0.712^{* *} \\ & (0.291) & (0.259) \\ \text { Log(Electricity) } & 2.12^{* *} & -0.128 \\ & (0.533) & (0.915) \\ \text { Constant } & 4.58^{*} & 13.98^{* *} \\ & (2.19) & (3.64) \\ \text { Number of Firms } & 22 & 22 \\ \mathrm{R}^{2} & 0.661 & 0.445 \\ \mathrm{R}^{2} \text { within } & & 0.259 \\ \text { Parameters } & 3 & 3 \\ \text { Observations } & 35 & 35\end{array}$

Electronics, Machinery and other Manufacturing

\begin{tabular}{lll}
$\log ($ Capital $)$ & 0.020 & -0.121 \\
& $(0.076)$ & $(0.105)$ \\
$\log ($ Labor $)$ & $1.095^{* *}$ & $1.101^{* *}$ \\
& $(0.135)$ & $(0.316)$ \\
$\log ($ Electricity) & $0.866^{* *}$ & -0.151 \\
& $(0.223)$ & $(0.442)$ \\
Constant & $8.25^{* *}$ & $15.16^{* *}$ \\
& $(1.10)$ & $(1.68)$ \\
Number of Firms & 82 & 82 \\
$\mathrm{R}^{2}$ & 0.618 & 0.500 \\
$\mathrm{R}^{2}$ within & & 0.272 \\
Parameters & 3 & 3 \\
Observations & 138 & 138 \\
\hline
\end{tabular}

*Significant at $10 \%$ leve1. **Significant at $1 \%$ level.

\section{Conclusions}

The analyses in this paper were an initial attempt in understanding the long-term relationship between income per capita in Pakistan and the expected growth in electricity consumption per capita. In addition to this, the paper looks at the impact of electricity prices and electricity inputs on manufacturing demand for electricity and manufacturing output. 
The important conclusions that arise from the paper are:

First, as income per capita in Pakistan increases, the consumption of electricity per capita will increase (at a rate of $0.65 \%$ increase in per capita consumption of electricity for every $1 \%$ increase in per capita income) at a relatively uniform rate, both because of significant increases in household consumption (which has already begun) and eventually higher industrial consumption, as the industrial base of Pakistan expands.

Second, as the pressure to increase electricity prices mounts, there will be strong household-level consequences (in terms of impacts on standards of living and on poverty) and, as this paper shows, significant impact on industrial demand for electricity and industrial output. The price elasticity of demand for electricity is approximately -0.6 in the manufacturing sector, although it is higher in the textile sector $(-0.8)$ and in the food sector (-0.7). This means that higher electricity prices will significantly reduce the demand for electricity in the manufacturing sector.

Third, the production function estimates show that output in the manufacturing sector is highly dependent on electricity inputs. Severe electricity shortages in small- and medium-scale industries, which do not have their own electricity generation capacity, will significantly reduce output. In the medium- and high-scale industries with their own electricity generation capacity, the switch to own power generation can have a significant impact on their cost of production.

So, continued electricity shortages will have a significant impact on manufacturing output. Also, any policies that lead to significant short-term increases in industrial electricity prices will also have to take into account the impact on manufacturing sector output. 


\section{References}

Aguirregabiria, V. (2009). Econometric Issues and Methods in the Estimation of Production Functions, Working Paper Number 15973, Munich Personal RePEc Archive.

Bental, B., and Ravid, S.A. (1982). A Simple Method for Evaluating the Marginal Cost of Unsupplied Electricity. The Bell Journal of Economics, 13(1), 249-253.

Bhattacharyya, S.C., and Timilsina, G.R. (2009).Energy Demand Models for Policy Formulation: A Comparative Study of Energy Demand Models. Policy Research Working Paper No. 4866, The World Bank, Development Research Group.

Bjørner, T.B., and Jensen, H.H. (2000). Industrial Energy Demand and the Effect of Taxes, Agreements and Subsidies. AKF Forlaget, Copenhagen.

Bjørner, T.B., Togeby, M., and Jensen, H.H. (2001). Industrial Companies' Demand for Electricity: Evidence from a Micropane1. Energy Economics, 23, 595-617.

Dimitropoulos, J., Hunt, L.C., and Judge, G. (2004).Estimating Underlying Energy Demand Trends using UK Annual Data. Surrey Energy Economics Discussion Paper 108, University of Surrey.

Fraser, J.M. (2005). Lessons from the Independent Private Power Experience in Pakistan. Energy and Mining Section Board Discussion Paper, 14. The World Bank Group: Washington, DC.

Government of India (2009). Economic Survey 2008-2009. Ministry of Finance, Government of India.

Government of Pakistan (Various Versions, 1992-2006). Economic Survey of Pakistan, Federal Bureau of Statistics.

Government of Pakistan (Various Versions, 2003-2006). Census of Electricity Establishments. Federal Bureau of Statistics, Energy \& Mining Statistics Section: Islamabad.

Griffin, J.M. (1993). Methodological Advances in Energy Modelling: 19701990. Energy Journal, 14(1), 111-14. 
Hathaway, R.M., Muchhala, B., and Kugelman, M. (eds) (2007). Fueling the Future: Meeting Pakistan's Energy Needs In The 21st Century. Woodrow Wilson International Center for Scholars: Washington, DC.

Heston, A., Summers. R., and Aten, B. (2009). Penn World Table Version 6.3, Center for International Comparisons of Production, Income and Prices at the University of Pennsylvania.

International Energy Agency (2009). Energy Prices \& Taxes. Quarterly Statistics, 3, International Energy Agency Publications (IEA): Paris.

Ishiguro, M., and Akiyama, T. (1995). Electricity Demand in Asia and the Effects on Energy Supply and the Investment Environment. Policy Research Working Paper No. 1557, The World Bank, International Economics Department, Commodity Policy and Analysis Unit.

Jones, C.T. (1996). A Pooled Dynamic Analysis of Interfuel Substitution in Industrial Energy Demand by the G-7 Countries. Journal of Applied Economics, 28, 815-821.

Jyoti, R., Ozbafli, A., and Jenkins, G. (2006). The Opportunity Cost of Electricity Outages and Privatization of Substations in Nepal. Queen's Economics Department Working Paper No. 1066, Queen's University, Canada.

Khan, A., Usman, M., and Usman, A. (2009). Energy Demand in Pakistan: A Disaggregate Analysis. Munich Personal RePEc Archive (MPRA) Paper No. 15056.

Kleijweg, A., Huigen, R., Leeuwen, G.van., and Zeelenberg, K. (1990). Firm Size and the Demand for Energy in Dutch Manufacturing, 19781986. Small Business Economics, 2,171-181.

Kumbhakar, S.C., and Heshmati, A. (1995). Efficiency Measurement in Swedish Dairy Farms: An Application of Rotating Panel Data, 197688. American Journal of Agricultural Economics, 77, 660-674.

LaCommare, K.H., and Eto, J.H. (2004).Understanding the Cost of Power Interruptions to U.S. Electricity Consumers. University of California, Ernest Orlando Lawrence Berkeley National Laboratory: Berkeley, California 94720. 
Lall, S.V., and Mengistae, T. (The Impact of Business Environment and Economic Geography on Plant Level Productivity: An Analysis of Indian Industry. Policy Research Working Paper No. 3664, The World Bank, Development Research Group.

Layton, D.F., and Moeltner, K. (2004). The Cost of Power Outages to Heterogeneous Households - An Application of the Mixed GammaLognormal Distribution. Forthcoming in Alberini, A., and Scarpa, R. (eds) Applications of Simulation Methods in Environmental and Resource Economics. Kluwer Academic Press.

Moeltner, K., and Layton, D.F. (2002). A Censored Random Coefficients Model for Pooled Survey Data with Application to the Estimation of Power Outage Costs. The Review of Economics and Statistics, 84(3), $552-561$.

Mundlak, Y. (1961). Empirical Production Function Free of Management Bias. Journal of Farm Economics, 43, 44-56.

Mundlak, Y., and I. Hoch (1965). Consequences of Alternative Specifications in Estimation of Cobb-Douglas Production Functions. Econometrica, $33,814-828$.

Pervez, A. (Compilation) (2009). Pakistan Power Sector. Consulate General of Switzerland Pakistan: Karachi.

Urga, G., and Walters, C. (2003). Dynamic Translog and Linear Logit Models: A Factor Demand Analysis of Interfuel Substitution in US Industrial Energy Demand. Energy Economics, 25, 1-21.

Woodland, A. (1993). A Micro-Econometric Analysis of the Industrial Demand for Energy in NSW. The Energy Journal, 14(2), 57-89.

World Bank (2002). Pakistan Enterprise Survey, World Bank Enterprise Analysis Unit, World Bank Group, Washington D.C.

World Bank (2007). Pakistan Enterprise Survey, World Bank Enterprise Analysis Unit, World Bank Group, Washington D.C. 


\section{Appendix-I}

Breakdown of Electricity Generation by Region (Source: International Energy Agency (2009). Energy Prices \& Taxes. Quarterly Statistics

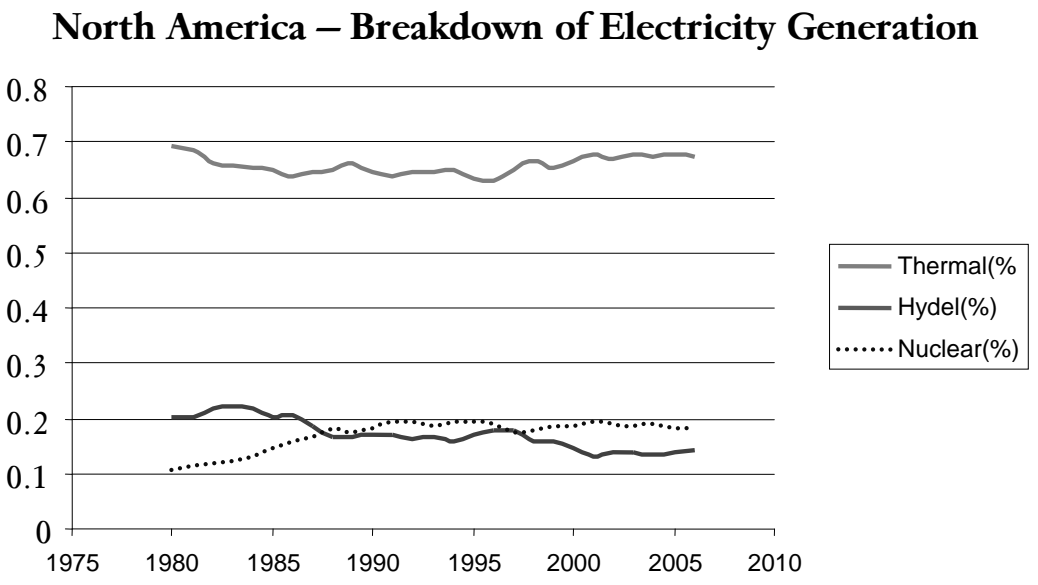

\section{Central and South America - Breakdown of Electricity Generation}

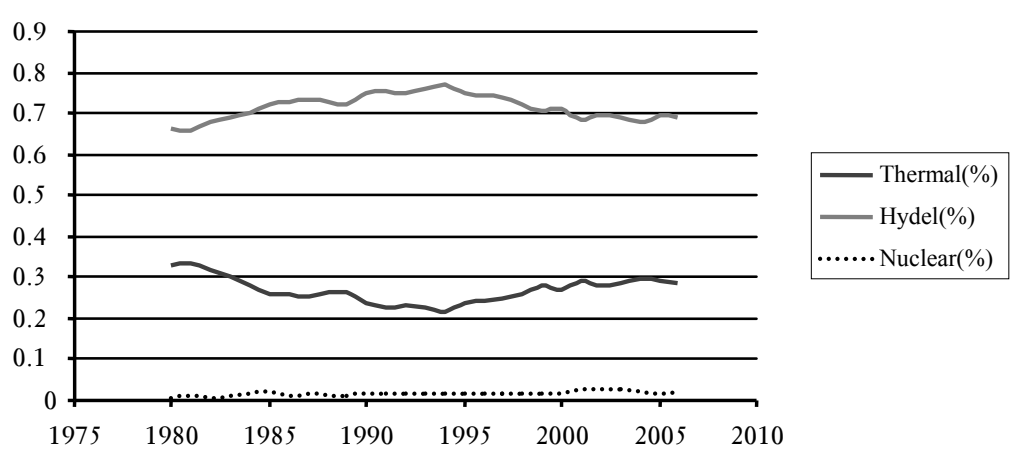

Europe - Breakdown of Electricity Generation

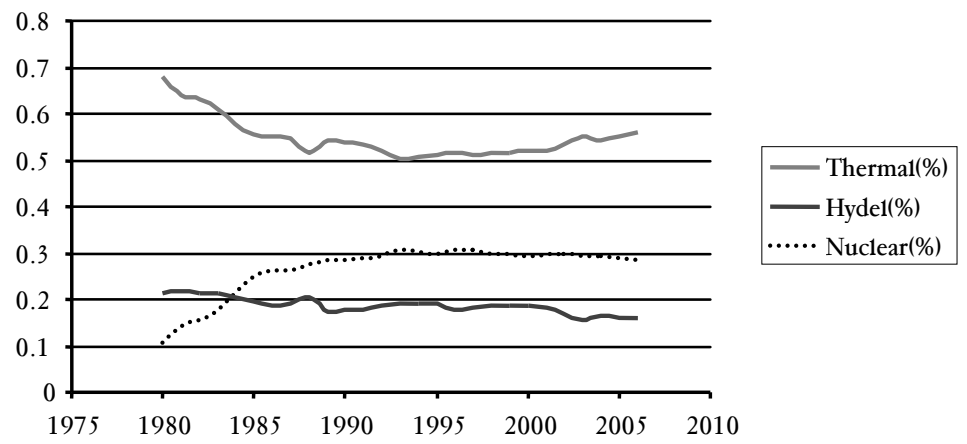




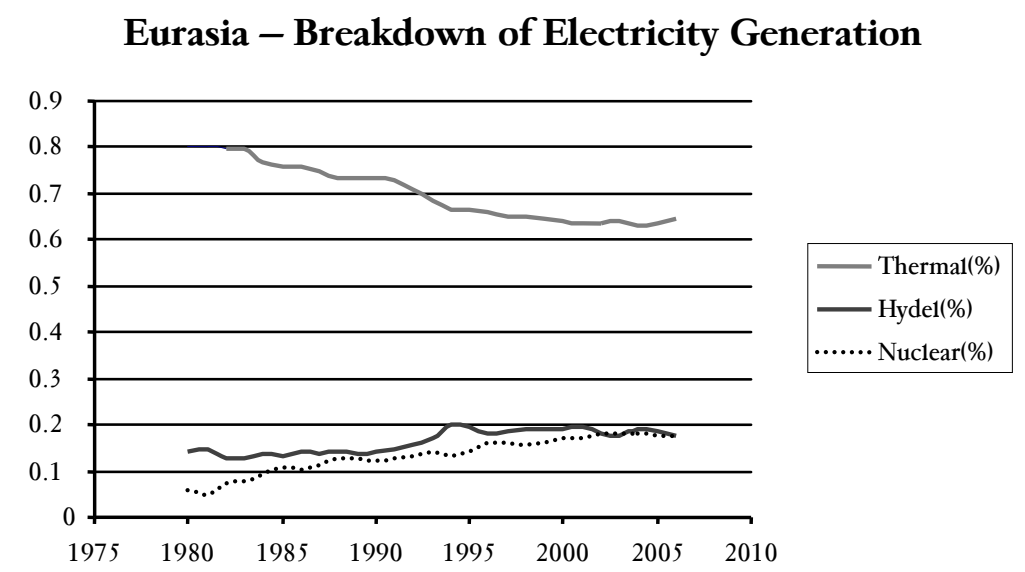

Middle East - Breakdown of Electricity Generation

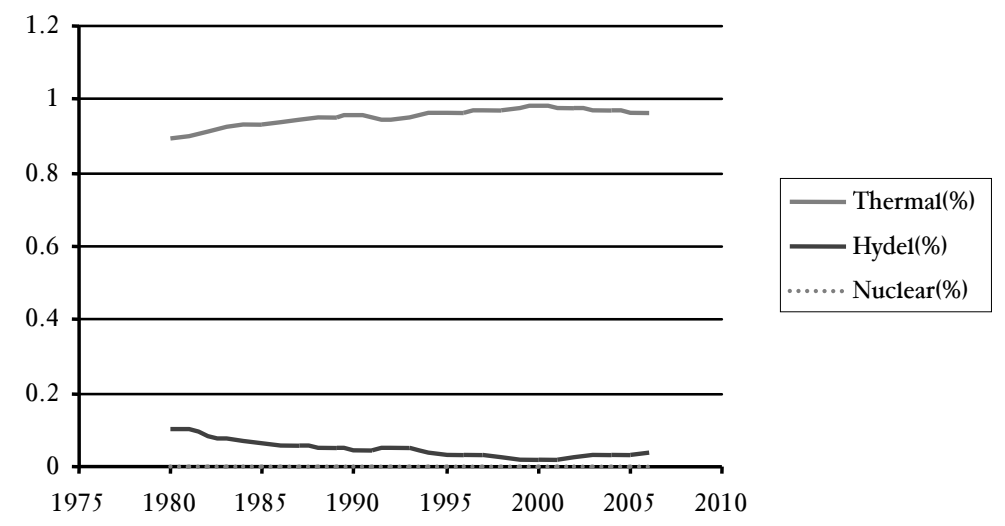

Africa - Breakdown of Electricity Generation

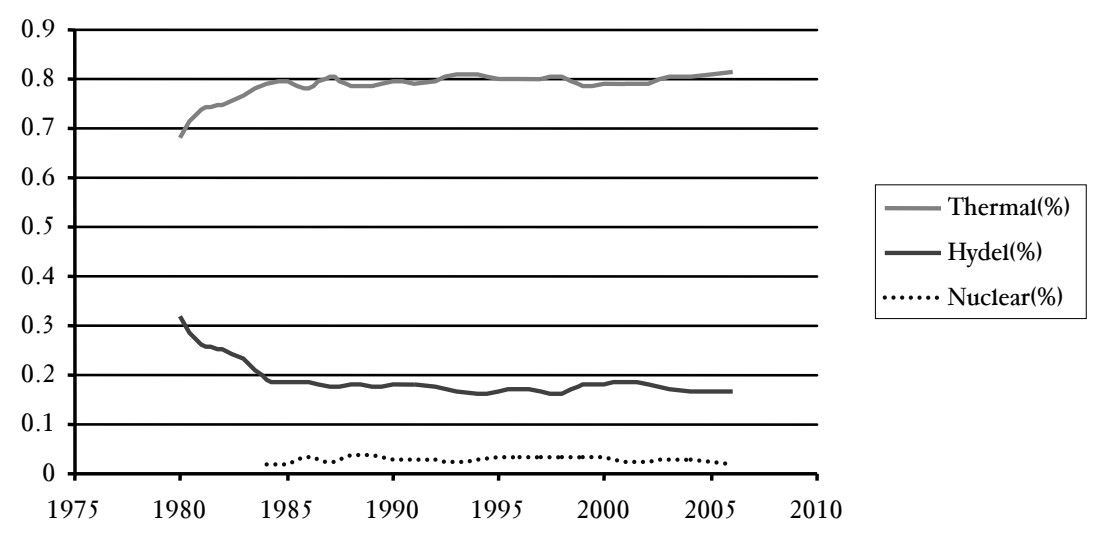

